\title{
EXPLORING THE IMPACT OF INTELLECTUAL CAPITAL COMPONENTS ON PROJECT PERFORMANCE
}

\author{
Nela Milošević, Marina Dobrota, Slađana Barjaktarović Rakočević \\ Faculty of Organizational Sciences, University of Belgrade, Serbia
}

\begin{abstract}
In today's knowledge-based business environment, intellectual capital (IC) is considered as an important contributor to project success. The aim of this paper is to question whether and, if so how, IC components (human, structural and relational capitals) influence project performance in the banking sector. Results show that all components of IC matter for project performance. More precisely, results demonstrate that a fair proportion of project performance (49.9\%) is accounted for human, structural and relational capital. The study contributes to IC theory by analysing its implementation in project management and banking industry. Moreover, practical contribution of this study is that intellectual capital, with the emphasise on structural capital, is crucial for project and service-oriented sectors such as banking sector.
\end{abstract}

Key words: human capital, structural capital, relational capital, project performance

\section{INTRODUCTION}

The concept of intellectual capital is not new, however there is a limited understanding of its definition and importance for organizational and project development. Additionally, the importance of the concept in today's knowledge based businesses becomes the essential part of economic progress. In the past, organizations considered tangible assets as most important for future development, but nowadays intangible assets become the key factor for competitive advantages. Ozkan, Cakan, \& Kayacan (2017) define intellectual capital as "the intangible assets which are not listed on a firm's balance sheet, but positively impact the performance of it". Sveiby (1997) defines intellectual capital as the way of acting in order to develop tangible and intangible assets in everyday environment. Lonnquist and Mettanen (2003) argue that one of the main characteristics of intellectual capital is to offer opportunities for the organization to be more successful in the future. In the study we follow (Gogan, Artene, Sarca, \& Draghici, 2016) definition of intellectual capital which consists of: human, relational and structural capital. Latas, \& Walasek (2016) point out that intellectual capital consists of "the possessed knowledge, experience, organizational technology, customer relationships and professional skills". Following the work of Meles, Porzio, Sampagnaro, \& Verdoliva (2016) who are focused on intellectual capital efficiency and its influence on financial performance in banking industry, we argue and show that intellectual capital is also very important for project performance within the banking industry. Having in mind that banking industry is one of the most knowledge-intense (Mavridis, \& Kyrmizoglou, 2005), we argue that it is an ideal setting for research on intellectual capital. Moreover, we argue that Serbia is a perfect example for conducting this type of research because there are 28 domestic and foreign banks operating in an underdeveloped financial market. We assume that the key differentiation factor for gaining a competitive advantage and reaching a high level of performance is intellectual capital. By drawing on project management literature, this study offers two relevant contributions. First, it empirically presents the overall mechanisms by which intellectual capital, more precisely human, structural and relational capital, enhance project performance. Second, it emphasizes the vital role played by intellectual capital in project management, which is then documented as one of the main determinants of

Corresponding author. Email: nela.milosevic@ fon.bg.ac.rs

ISSN 2560-4961 (online)

(C) 2018 IPMA Serbia

doi: 10.18485/epmj.2018.8.2.6 
project performance in today's banking industry.

The findings show that structural capital has the strongest relationship with project performance, followed by human capital and relational capital. Furthermore, structural capital influences project performance while human capital and relational capital were found to have statistically insignificant effects.

Following the introductory section, Section 2 provides the literature review and hypotheses development. Section 3 presents method and data collection and Section 4 focuses on the results. Section 5 contains conclusion, contributions and limitations.

\section{LITERATURE REVIEW AND HYPOTHESIS DEVELOPMENT}

Intellectual capital can be defined as "the sum of all intangible and knowledge-related resources than an organization is able to use in its productive processes in the attempt to create value " (Kianto, Ritala, Spender, \& Vanhala, 2014). The strength of the organization and its performance depends on its intellectual capital. Numerous methods can be used in order to measure intellectual capital (Edvinsson, 1997; Roos, Edvinsson, \& Dragonetti, 1997) and all of them suggest that intellectual capital positively affect profitability, efficiency and some financial markets' performance measures (Firer, \& Stainbank, 2003; Makki, Lodhi, \& Rohra, 2009). For example, one of the most used model is VAIC model developed by Pulic (1998) and Pulic (2004). The VAIC model consists of three coefficients: capital employed coefficient, human capital efficiency coefficient and structural efficiency coefficient. Inkinen (2015) suggests that intellectual capital has a positive impact on overall performance. Moreover, Inkinen (2015) finds that intellectual capital contributes to innovation performance.

All three parts of intellectual capital, human, structural and relational, are inevitable factors for growth and development of organizations especially nowadays in constantly changing economic environment. Human capital refers to the firm's employees and their knowledge, capabilities, education, skills and characteristics (Bontis, 1998).
Structural/organizational capital remains even when people leave the organization (Roos, \& Roos, 1997), while relational or social capital is the value of relationships with stakeholders (Edvinsson, \& Malone, 1997). The way in which organizations use their knowledgebased resources and capabilities becomes the main factor that explains differences in competitive performance (Ramezan, 2011). Handzic, Durmic, Kraljic, \& Kraljic (2016) develop a conceptual model which tests the relationship between project-specific intellectual assets and project success. They point out that project's structural capital (e.g. process), human capital (e.g. team) and relational capital (e.g. customer) have mediating role within the optimal intellectual capital structure.

Handzic, et al. (2016) define project success as "the ultimate target value expected to be realized through harnessing project related intellectual capital". Moreover, Jovanović, Milijić, \& Stojanović (2017) point out that different knowledge management factors are crucial for the achievement of project goals. In IT industry, around 70 per cent of projects failed and one of the most common reasons for such a high project failure rate is the nonefficient use of knowledge assets (Handzic, et al., 2016; Yeong, \& Lim, 2010). In order to be successful, a project has to be completed within the defined time, budget and scope constraints (De Bakker, Boonstra, \& Wortmann, 2010). In this paper, we analyse overall project performance including operational and technical goals and objectives, budget, expectations and results.

The purpose of this research is to understand the association between intellectual capital and project performance. Specifically, the main objective of the study is to analyse how different parts of intellectual capital - human, relational and structural capital - influence project performance within the banking industry.

\subsection{Human capital and project performance}

Employees are considered as the most valuable resource in organizations. They contribute to intellectual capital through their competence, capabilities and intellectual agility (Bontis, 
Crossan, \& Hulland, 2002). Additionally, all the human capital attributes are focused on employees and include their know-how, skills, values, motivation, learning capacity, behaviour etc. (see Andreeva, \& Garanina, 2016; Chien, \& Chao, 2011; Leitner, 2011). Turner, Maylor, \& Swart (2015) define two types of knowledge regarding human capital: (1) specialist knowledge that includes project management knowledge, and knowledge of relevant tools and technics for project management and (2) generalist knowledge which takes into account previous experience and understanding of the project through business strategy and operations. Therefore, we argue that human capital positively influences project performance.

\subsection{Relational capital and project performance}

Nowadays, many stakeholders influence organizational development by creating the network of customers, banks, shareholders and other agents who can contribute to the particular organization (for more see Cabrita, \& Bontis, 2008). Relational capital can be divided into internal and external relational capital (Andreeva, \& Garanina, 2016). Internal relational capital refers to cooperation between employees and departments. External capital focuses on the cooperation with suppliers and customers, and includes brands, alliances and different types of agreements (Andreeva, \& Garanina, 2016). It has been shown that longterm relationships with stakeholders affect project performance and influence organizational competitive position (Snehota, \& Hakansson, 1995). Therefore, we propose that relational capital positively influences project performance.

\subsection{Structural capital and project performance}

Meles, et al. (2016) define structural capital as "the complex of goods and knowledge of an organization, including its procedures, databases, routines, hardware and organizational culture." Moreover, Bontis (1998) points out that structural capital represents organizational culture that supports new employees' ideas. Structural capital refers to all supportive elements such as corporate culture, strategy, programmes etc. (see Hsu, \& Fang, 2009; Kamukama, Ahiauzu, \& Ntayi, 2010). Andreeva, \& Garanina (2016) define corporate culture, management procedures, information and decision-making systems as some parts of the knowledge kept in organizations - structural capital. Turner, et al. (2015) suggests that strong relationships are very important for successful project functioning. Therefore, we hypothesize that structural capital positively influences project performance.

\subsection{Model}

Based on the literature review given above, as well as the objectives of our research, we propose the following model which includes the hypothesized variables, discussed in the paragraphs above:

$$
P P_{i}=\beta_{0}+\beta_{1} H C_{i}+\beta_{2} S C_{i}+\beta_{3} R C_{i}+\varepsilon_{i}
$$

Where $P P_{i}$ is dependent variable Project Performance. Explanatory variables are three hypothesizes variables - $H C_{i}$ is Human capital, $S C_{i}$ is Structural capital, $R C_{i}$ is Relational capital; $\beta_{0} \ldots \beta_{3}$ are regression coefficients, and $\varepsilon_{i}$ is a stochastic error, entities $i=1,2 \ldots n$. 


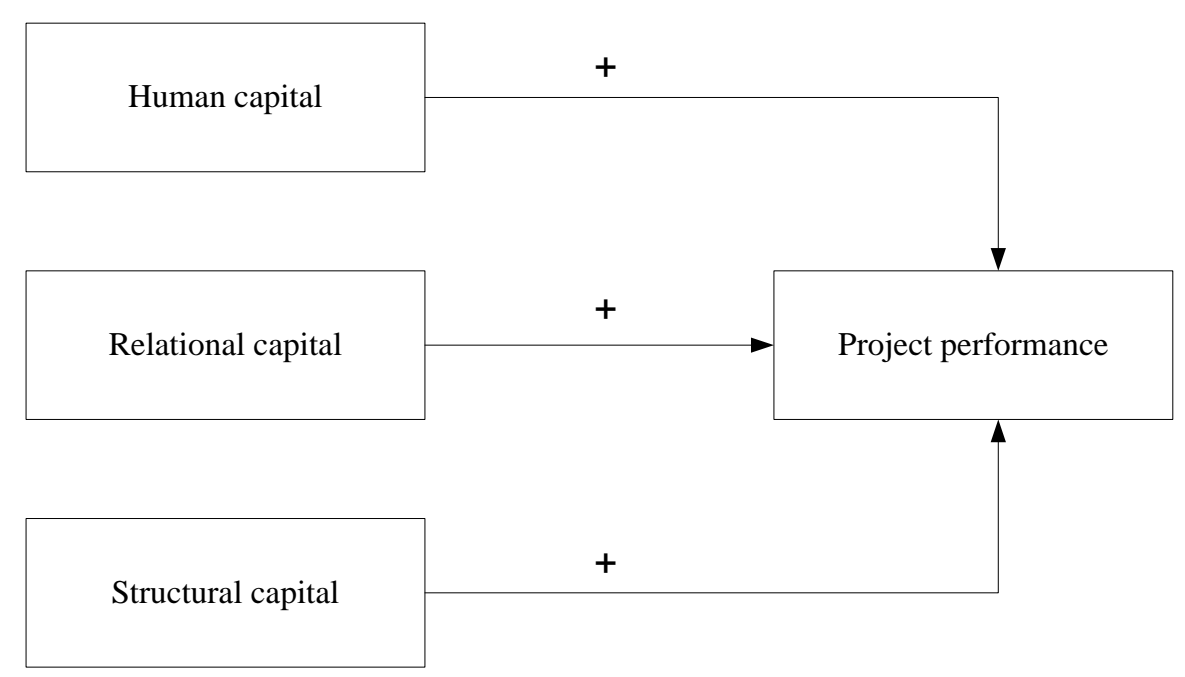

Figure 1: Hypothesised model of relationship between intellectual capital components and project performance

\section{METHOD AND DATA COLLECTION}

The target population for the study consists of CEOs and managers from the banking industry. The response rate was $64 \%$ which has provided us with a sample of 32 cases from the Serbian banking industry. To ensure relative representativeness and variety of the data, the sample includes three banking sectors: Strategic Marketing, Retail, and Project Management Department. The age of respondents ranges from 29 to 55, with a mean value of 38.5 years and a standard deviation of 5.829. The survey includes 20 females and 12 males. Confidentiality was guaranteed and a report of the results was promised to the respondents. A survey that tests the described research model was conducted in Serbia. Before we engaged in the formal data collection, a pilot survey was tested. Whenever possible, measured items were adjusted from the existing scales in the literature. We have cautiously modified the scales in accordance with the context of Serbian banking industry. All variables are defined in the Appendix A, with the structure given in detail.

\section{RESULTS}

As a first step of the analysis, the reliability and validity of the measurement scales were investigated. All scale items have Cronbach's alpha over the threshold of 0.8 , indicating good validity of the scales. Table 1 presents descriptive statistics for variables used in the study, and their Cronbach's alpha measures. The variables were calculated as the average values of their structural components.

Table 1: The descriptive properties of scales defined in the research

\begin{tabular}{llllll}
\hline & Minimum & Maximum & Mean & Std. Dev. & Cronbach's alpha \\
\hline Project performance & 2.80 & 5.00 & 3.76 & 0.591 & 0.813 \\
Human capital & 2.60 & 5.00 & 3.81 & 0.659 & 0.867 \\
Structural capital & 2.29 & 4.29 & 3.34 & 0.601 & 0.811 \\
Relational capital & 2.40 & 5.00 & 4.09 & 0.605 & 0.892 \\
\hline
\end{tabular}

As a next step, regression analysis was performed to test the relationship between different intellectual capital elements and project performance. Results are presented in Table 2. 
Table 2: Pearson correlation coefficients for project performance attributes

$$
\text { Human Capital Structural capital Relational capital }
$$

\begin{tabular}{llll}
\hline Structural capital & $0.579 * *$ & & \\
Relational capital & $0.761^{* * *}$ & $0.671^{* * *}$ & \\
Project performance & $0.56^{* * *}$ & $0.674 * * *$ & $0.526^{* *}$ \\
\hline
\end{tabular}

$* \mathrm{p}<0.05 * * \mathrm{p}<0.01 * * * \mathrm{p}<0.001$

To examine the influence and intensity of human, structural, and relational capital on project performance, the study used linear regression analysis as displayed in Table 3. The results suggest that the examined attributes explain $49.9 \%\left(R^{2}=0.49918\right)$ of variability of dependent variable - perceived project performance, as well as that the defined model is significant $(\mathrm{F}=9.302 ; \mathrm{p}<0.001)$.

Table 3: OLS regression model for project performance

\begin{tabular}{llll}
\hline & Project performance & & \\
\hline & Regression coefficients & t-statistics & Sig. \\
\hline Intercept & 1.223 & & \\
Human capital & 0.261 & 1.401 & 0.172 \\
Structural capital & 0.539 & 3.010 & 0.005 \\
Relational capital & -0.063 & -0.284 & 0.779 \\
\hline
\end{tabular}

In our model, intellectual capital components explain nearly 50\% of the variability of Project performance. Our results are in line with results in Handzic et al. (2016) who find that intellectual capital has a positive effect on project success. Additionally, researchers point out that intellectual capital can be a valuable predictor of future projects' performance.

One must note that all components of intellectual capital have the positive relationships with project performance. The Relational capital variable has the lowest correlation coefficient $(\mathrm{r}=0.526)$, which can be seen in Table 2. Human capital correlation coefficient is slightly higher than the
Relational capital ( $\mathrm{r}=0.56)$, and still significant. Moreover, structural capital has the strongest relationship with project performance $(\mathrm{r}=0.674)$.

However, if we observe the multivariate model of the intellectual capital components, we can see that the Structural capital completely dominates the influence on Project performance, comparing to the Human capital and Relational capital. In the model given in Table 3, structural capital has repressed the influence of other two elements. Figure 2 presents the relationship between Structural capital and Project performance.

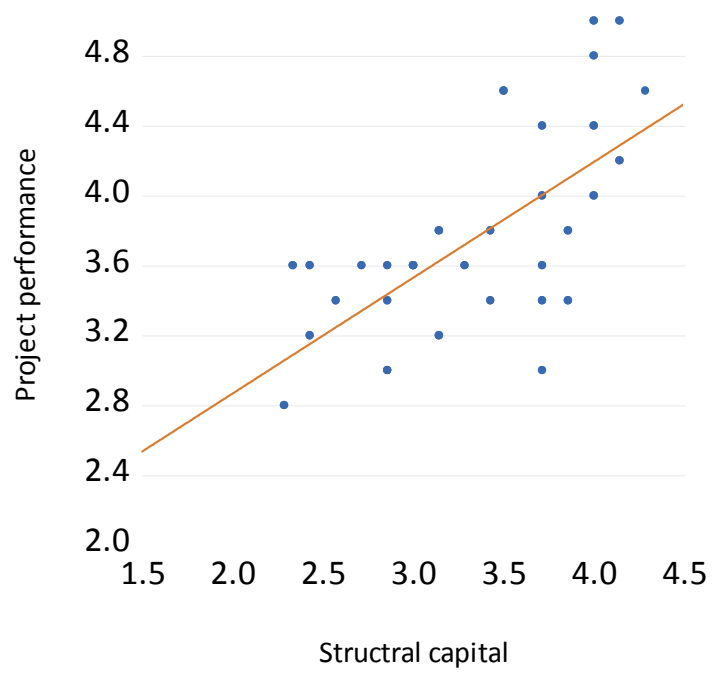

Figure 2: The relationship between Structural capital and Project performance 


\section{CONCLUSION AND LIMITATIONS}

The purpose of this study is to analyse the relationships between human, relational and structural capital and project performance.

This research offers several contributions. While many papers discuss the relationship between intellectual capital and organizational performance, there is no research that focuses on influence of intellectual capital on project performance. Moreover, it has been shown that intellectual capital has an important role in companies' performance (Meles et al., 2016), but there is a lack of empirical evidence from banking industry. Additionally, by explaining all parts of intellectual capital we show that human, structural and relational capital are crucial for project performance improvement. Moreover, our research extends literature on intellectual capital and project performance in the banking industry. Finally, practical contribution of this study is that intellectual capital, with the emphasise on structural capital, is crucial for project and serviceoriented industries such as banking industry.

The study is subject to some limitations. First, the survey methodology has potential for measurement error, even though we were trying to avoid all methodological weaknesses trough the study design. Second, variables are based on perceptions of employees who are single respondents, which implies certain degree of subjectivity. Having in mind that every respondent provided data for dependent and independent variables in the same time, common method bias might cause some problems. However, the possibility of common method bias decreases because we used experts from the banking industry and different scales for each variable. Finally, the study focuses only on intellectual capital and general performance, but the approach can be applied to other industries in order to analyse the importance of intellectual capital in other environments. Despite all these limitations, causal relationships between parts of intellectual capital and project performance, and the importance of the topic, cannot be neglected.

\section{Acknowledgements}

This paper is a result of Strategic Project founded by the Ministry of Education, Science and Technological Development of the Republic of Serbia: Exploring modern trends of strategic management by application of specialized management disciplines in the function of the competitiveness of Serbian economy, No 179081.

\section{REFERENCES}

Andreeva, T., \& Garanina, T. (2016). Do all elements of intellectual capital matter for organizational performance? Evidence from Russian context. Journal of Intellectual Capital, 17(2), 397-412. https://doi.org/10.1108/jic-07-2015-0062

Bontis, N. (1998). Intellectual capital: an exploratory study that develops measures and models. Management decision, 36(2), 63-76.

Bontis, N., Crossan, M. M., \& Hulland, J. (2002). Managing an organizational learning system by aligning stocks and flows. Journal of management studies, 39(4), 437-469. https://doi.org/10.1111/1467-6486.t01-100299

Cabrita, M. D. R., \& Bontis, N. (2008). Intellectual capital and business performance in the Portuguese banking industry. International Journal of Technology Management, 43(1-3), 212237.

https://doi.org/10.1504/ijtm.2008.019416

Chien, S. H., \& Chao, M. C. (2011). Intellectual capital and new product sale performance of the financial services industry in Taiwan. The Service Industries Journal, 31(16), 2641-2659. https://doi.org/10.1080/02642069.2010.5 $\underline{06572}$

De Bakker, K., Boonstra, A., \& Wortmann, H. (2010). Does risk management contribute to IT project success? A meta-analysis of empirical evidence. International Journal of Project Management, 28(5), 493-503. https://doi.org/10.1016/j.ijproman.2009.0 7.002

Edvinsson, L. (1997). Developing intellectual capital at Skandia. Long range 
planning, 30(3),

https://doi.org/10.1016/s0024-

6301(97)90248-x

Edvinsson, L., \& Malone, M. S. (1997). Intellectual capital: realizing your company's true value by finding its hidden brainpower.

Firer, S., \& Stainbank, L. (2003). Testing the relationship between intellectual capital and a company's performance: evidence from South Africa. Meditari Accountancy Research, 11(1), 25-44. https://doi.org/10.1108/10222529200300 003

Gogan, L. M., \& Artene, A., Sarca, I., \& Draghici, A. (2016). The impact of intellectual capital on organizational performance. Procedia-social and behavioral sciences, 221, 194-202. doi:10.1016/j.sbspro.2016.05.106

Handzic, M., Durmic, N., Kraljic, A., \& Kraljic, T. (2016). An empirical investigation of the relationship between intellectual capital and project success. Journal of Intellectual Capital, 17(3), 471-483. https://doi.org/10.1108/jic-01-2016-0004

Hsu, Y. H., \& Fang, W. (2009). Intellectual capital and new product development performance: The mediating role of organizational learning capability. Technological Forecasting and Social Change,76(5), 664-677. https://doi.org/10.1016/j.techfore.2008.0 3.012

Inkinen, H. (2015). Review of empirical research on intellectual capital and firm performance. Journal of Intellectual capital, 16(3), 518-565. https://doi.org/10.1108/jic-01-2015-0002

Jovanović, I., Milijić, N., \& Stojanović, A. (2017). Modelling of knowledge management factors in project organizations. European Project Management Journal, 7 (1), 13-23.

Kamukama, N., Ahiauzu, A., \& Ntayi, J. M. (2010). Intellectual capital and performance: testing interaction effects. Journal of Intellectual Capital, 11(4), 554-574. https://doi.org/10.1108/14691931011085 687
Kianto, A., Ritala, P., Spender, J. C., \& Vanhala, M. (2014). The interaction of intellectual capital assets and knowledge management practices in organizational value creation. Journal of Intellectual capital, 15(3), 362-375. https://doi.org/10.1108/jic-05-2014-0059

Latas, R., \& Walasek, D. (2016). Intellectual capital within the project management. Procedia Engineering, 153, 384-391.

doi:10.1016/j.proeng.2016.08.137

Leitner, K. H. (2011). The effect of intellectual capital on product innovativeness in SMEs. International Journal of Technology Management, 53(1), 1-18. https://doi.org/10.1504/ijtm.2011.037235

Lonnquist, A., \& Mettanen, P. (2003) Criteria for sound intellectual capital statements, Institute of Industrial Management, Tampere University of Technology, Finland

Makki, M. A. M., Lodhi, S. A., \& Rohra, C. L. (2009). Impact of intellectual capital on shareholders earning. Australian Journal of Basic and Applied Sciences, 3(4), 3386.

Mavridis, D. G., \& Kyrmizoglou, P. (2005). Intellectual capital performance drivers in the Greek banking sector. Management Research News, 28(5), 43-62. https://doi.org/10.1108/01409170510629 032

Meles, A., Porzio, C., Sampagnaro, G., \& Verdoliva, V. (2016). The impact of the intellectual capital efficiency on commercial banks performance: Evidence from the US. Journal of Multinational Financial Management, 36, 64-74. http://dx.doi.org/10.1016/j.mulfin.2016.0 4.003

Ozkan, N., Cakan, S., \& Kayacan, M. (2017). Intellectual capital and financial performance: A study of the Turkish Banking Sector. Borsa Istanbul Review, 17(3), 190-198. https://doi.org/10.1016/j.bir.2016.03.001

Pulic, A. (1998, January). Measuring the performance of intellectual potential in knowledge economy. In 2nd McMaster Word Congress on Measuring and Managing Intellectual Capital by the Austrian Team for Intellectual Potential. 
Pulic, A. (2004). Intellectual capital-does it create or destroy value?. Measuring business excellence, 8(1), 62-68. https://doi.org/10.1108/13683040410524 757

Ramezan, M. (2011). Intellectual capital and organizational organic structure in knowledge society: How are these concepts related?. International Journal of Information Management, 31(1), 8895.

https://doi.org/10.1016/j.ijinfomgt.2010.1 0.004

Roos, G., \& Roos, J. (1997). Measuring your company's intellectual performance. Long range planning, 30(3), 413-426. https://doi.org/10.1016/s00246301(97)90260-0

Roos, J., Edvinsson, L., \& Dragonetti, N. C. (1997). Intellectual capital: Navigating the new business landscape. Springer. https://doi.org/10.1007/978-1-34914494-5

Snehota, I., \& Hakansson, H. (Eds.). (1995). Developing relationships in business networks. London: Routledge.

Sveiby, K. E. (1997). The new organizational wealth: Managing \& measuring knowledge-based assets. Berrett-Koehler Publishers.

Turner, N., Maylor, H., \& Swart, J. (2015). Ambidexterity in projects: An intellectual capital perspective. International Journal of Project Management, 33(1), 177-188. http://dx.doi.org/10.1016/j.ijproman.2014 .05 .002

Yeong, A., \& Lim, T. T. (2010). Integrating knowledge management with project management for project success. Journal of Project, Program \& Portfolio Management, 1(2), 8-19. https://doi.org/10.5130/pppm.v1i2.1735 
Appendix A

\begin{tabular}{|c|c|}
\hline Scale & Structural components \\
\hline $\begin{array}{l}\text { Human } \\
\text { capital }\end{array}$ & $\begin{array}{l}\text { - Employees hold suitable work experience for accomplishing their job } \\
\text { successfully in our Bank. } \\
\text { - Employees of our Bank have excellent professional skills in their } \\
\text { particular jobs and functions. } \\
\text { - The company provides well-designed training programs. } \\
\text { - The employees of our Bank often develop new ideas and knowledge. } \\
\text { - Employees are creative in our company. }\end{array}$ \\
\hline $\begin{array}{l}\text { Structural } \\
\text { capital }\end{array}$ & $\begin{array}{l}\text { - } \quad \text { The overall operations procedure of our Bank is very efficient. } \\
\text { - } \text { Our Bank responds to changes very quickly. } \\
\text { - } \quad \text { Our Bank has an easily accessible information system. } \\
\text { - } \quad \text { Systems and procedures of our Bank support innovation. } \\
-\quad \text { Our Bank's culture and atmosphere are flexible and comfortable. } \\
-\quad \text { Our Bank emphasizes new market development investment. } \\
-\quad \text { There is support among different departments in our Bank. }\end{array}$ \\
\hline $\begin{array}{l}\text { Relational } \\
\text { capital }\end{array}$ & $\begin{array}{l}\text { - Our Bank discovers and solves problems through intimate communication } \\
\text { and effective collaboration. } \\
\text { - Our Bank maintains appropriate interactions with its stakeholders. } \\
\text { - Our Bank maintains long-term relationships with customers. } \\
\text { - Our Bank has many excellent partners. } \\
\text { - Our Bank has stable and good relationships with the strategic partners. }\end{array}$ \\
\hline $\begin{array}{l}\text { Project } \\
\text { performance }\end{array}$ & $\begin{array}{l}\text { - } \text { Projects meet their operational performance goals. } \\
\text { - } \quad \text { Projects meet their technical performance goals. } \\
\text { - } \quad \text { Projects meet their schedule objectives. } \\
\text { - } \quad \text { Projects stay within budget limits. } \\
\text { - } \quad \text { Project results meet stakeholders' expectations. }\end{array}$ \\
\hline
\end{tabular}

